\title{
EFEKTIVITAS KEPEMIMPINAN KEPALA SEKOLAH DALAM MENINGKATKAN KEMAMPUAN GURU MENYUSUN RPP DI MAS AL-IKHWAN SERAPUH
}

\author{
Rani Febriyanni $^{1}$, Satria Wiguna ${ }^{2}$, Novira Arafah ${ }^{3}$, Rizki Akmalia $^{4}$ \\ Manajemen Pendidikan Islam STAI Jam'iyah Mahmudiyah Tanjung Pura ${ }^{1,3,4}$ \\ Pendidikan Agama Islam STAI Jam'iyah Mahmudiyah Tanjung Pura ${ }^{2}$ \\ email korespondensi: ranifebriyanni1991@gmail.com,Satria_Wiguna@staijm.ac.id, \\ novira.arafah2121@gmail.com, rizki.akmalia@gmail.com
}

\begin{abstract}
The specific objectives of this research are to 1). Knowing the Principal's Leadership at Al-Ikhwan Assalam Islamic Boarding School; 2). Knowledge of the principal's socialism in leading the Al-Ikhwan Assalam Islamic Boarding School. 3). Knowing the professionalism of the leadership of school principals at the Al-Ikhwan Assalam Islamic Boarding School; 4). Finding and analyzing the effectiveness of the principal's leadership in improving teacher competence on lesson plans at the Al-Ikhwan Assalam Islamic Boarding School. This type of qualitative research with a descriptive approach. Methods of collecting data by means of observation, interviews, and documentation. Techniques of data analysis by reduction, data presentation, drawing conclusions, or verification. The results of the research and discussion show that from the socialist perspective of the principal, it is known that the principal's social competence is in establishing good relationships with internal and external parties of the school. In terms of Managerial Leadership in the ability of teachers to prepare lesson plans by providing directions, instructions for implementing learning, supervision, and evaluation of activities, in terms of the ability of school principals who are able to protect, provide examples and solve problems and achievements at the MAS Al-Ikhwan Assalam school. The Effectiveness of Principal Leadership in Improving Teacher Competence, RPP, the results show that most teachers are able to be independent in making and compiling lesson plans.
\end{abstract}

Keywords: Principal, Teacher Ability to Prepare RPP

Pemimpin formal atau biasanya disebut kepala sekolah/madrasah ialah "seorang (pria atau wanita), yang oleh organisasi tertentu (swasta atau pemerintah), ditunjuk (berdasarkan surat-surat keputusan pengangkatan dari organisasi yang bersangkutan) untuk memangku suatu jabatan dalam struktur organisasi yang ada, dengan segala hal dan kewajiban yang berkaitan dengannya, untuk mencapai sasaran-sasaran organisasi tersebut yang ditetapkan sejak semula (Mesiono, 2012). Kepala sekolah ialah seorang pemimpin yang mempunyai tanggung jawab pada kepemimpinannya, dalam hal ini yakni guru, tenaga administrasi, siswa/I dan tenaga kebersihan yang ada di lingkup sekolahnya. Tugas dan fungsi kepala sebagai seorang pemimpin amatlah luas dan beragam, terutama terkait proses kegiatan belajar dan mengajar. Mulai dari perencanaan, 
urgensi, hingga keberhasilan. Semuanya dapat diukur kefektifaannya. Kepala sekolah bersinergi untuk membantu problematika yang dihadapi oleh bawahannya, mulai dari memperkenalkan, mengemukakan dan mendeskripsikan pembaharuan yang terus berkembang dari waktu ke waktu (Marpaung 2014). Apabila ditemukannya kendala, kesulitan dan sebagainya dalam hal pelaksanaan dan penerapan. Lebih dari itu, rutinanitas yang berkesinambungan dalam membina dan mengawasi juga tak boleh diabaikan, untuk melihat kinerja, mengukur serta mengetahui ketercapaian pelaku dan penerima pembelajaran (Sangad, 2016). Guru sebagai seseorang yang memiliki kemampuan untuk mengintervensi peserta didik pada suatu lembaga khususnya pendidikan. Seorang guru didesain dengan kecakapan yang terangkum, diantaranya : kognitif, kepribadian, social dan professional (Wiguna, 2020). RPP merupakan perangkat terkecil dari proses mengajar yang harus dimiliki oleh seorang guru (Kamiludin, 2021). Hal ini termaktub didalam Permendiknas Nomor 41 Tahun 2007, Rencana Pelaksanaan Pembelajaran (RPP) adalah rencana yang menggambarkan prosedur dan pengorganisasian pembelajaran untuk mencapai satu kompetensi dasar yang ditetapkan dalam standar isi dan telah dijabarkan dalam silabus. RPP adalah rencana pembelajaran yang dikembangkan secara rinci dari satu materi pokok atau tema yang mengacu pada silabus (Permen 81 A). PP RI Nomor 19 Tahun 2005 Pasal 20 dinyatakan bahwa : perencanaan proses pembelajaran yang sekurangkurangnya meliputi tujuan pembelajaran, materi dan metode ajar, sumber dan penilaian hasil belajar.

Pada observasi awal yang dilakukan, ada beberapa guru yang ditemukan masih belum mampu merancang dan menyusunnya. Padahal sudah diadakan penyusunan eksternal yang diakomodisir oleh pengawas sekolah. Hal ini terjadi disebabkan kurang maksimalnya waktu belajar penyusunan RPP, praktek yang diadakan tidak menyeluruh ke semua guru, ataupun mengandalkan internet sebagai rujukan inti tetapi tidak memahami pada setiap komponen di dalam RPP. Oleh sebab itu, diperlukan Penyusunan internal baik antar sesama guru selaku teman sejawat maupun antar atasan kepada bawahan. Maka dari itu, peneliti tertarik untuk menggali mengenai Efektivitas Kepemimpinan Kepala Sekolah

Rani Febriyann et.al (Eektivitas Kepemimpinan Kepala p-ISSN2580-7056; e-ISSN2580-7064
Sekdah)
Da. $10.2397 /$ tf. v5i23244


dalam Meningkatkan Kompetensi Guru Menyusun RPP di Madrasah Aliyah Swasta Assalam.

Pada tercapainya keefektifan kepemimpinan kepala madrasah dalam peningkatan kompetensi guru menyusun RPP maka perlu mengetahui empat kompetensi yang wajib dimiliki oleh kepala sekolah, yaitu : manajerial, sosial dan professional(Badeni 2013). RPP merupakan komponen yang harus disediakan oleh guru sebelum mengajar di kelas. Apabila dalam penyusunannya guru tidak memahami sebagaimana standar yang telah ditetapkan, maka akan memunculkan materi yang tidak sinkron, bahan ajar yang kurang up to date(Danim 2004). Berdasarkan hal tersebut maka perlu adanya perbaikan dimulai dari kepala sekolah sebagai penanggung jawab sekolah dan civitas yang ada didalamnya dengan kemampuan yang dimilikinya. Lebih jauh lagi, dijelaskan bahwa kepala sekolah/madrasah harus menanggapi komponen lain, yakni para pendidik (Arafah,2017). Mereka bertanggung jawab untuk meningkatkan profesionalitas kerja di sekolah, mengatasi praktik-praktik buruk dan tidak layak, baik di ruangan kelas maupun di lingkungan sekolah, mengapresiasi hasil kerja yang istimewa dari para siswa maupun guru, dan menyediakan kesempatan pengembangan profesi bagi staffnya(Asrul, 2013).

\section{METODE}

Penelitian ini merupakan jenis penelitian lapangan dengan pedekatan kualitatif. Dalam penelitian kualitatif data yang dikumpulkan bukan angka-angka, akan tetapi berupa kata-kata atau gambaran yang dimaksud berasal dari wawancara, catatan lapangan, foto, dokumen pribadi dan lainnya(Sugiyono 2010). Oleh karena itu dalam penelitian ini menggunakan pendekatan deskriptif. Penelitian kualitatif digunakan untuk mengungkap data deskriptif dari informasi tentang apa yang mereka lakukan dan yang mereka alami terhadap fokus penelitian, yang bekaitan dengan efektivitas kepemimpinan kepala sekolah sebagai pemimpin dalam meningkatkan kemampuan guru menyusun RPP. Teknik Pengumpulan data dengan cara observasi, wawancara dan dokumentasi. Yang menjadi informan pada penelitian ini adalah kepala sekolah dan guru Madarasah 
Aliyah Swasta Assalam Serapuh. Teknik analisis data dalam penelitian ini yaitu dari data reduction (reduksi data), data display (penyajian data), conclution drawing or verification (penerikan kesimpulan atau verifikasi),

Adapun tahapan penelitian ini dilaksanakan yaitu:

1. Tahapan Persiapan, pada tahapan persiapan ini peneliti mulai mengumpulkan buku-buku atau teori-teori yang berkaitan dengan pembahasan penelitian mengenai efektivitas kepemimpinan kepala sekolah sebagai pemimpin dalam meningkatkan kemampuan guru menyusun RPP

2. Tahap Pelaksanaan, pada tahap ini dilaksanakan dengan cara mengumpulkan data-data yang berkaitan dengan fokus penelitian dari lokasi penelitian. Dalam proses pengumpulan data ini peneliti menggunakan metode observasi. Setelah mendapat ijin dari Kepala Sekolah, peneliti kemudian mempersiapkan diri untuk memasuki lembaga tersebut demi terciptanya informasi sebanyak-banyaknya dari kepala sekolah, guru dan siswa.

Peneliti terlebih dahulu menjalin keakraban dengan responden dalam berbagai aktifitas, agar peneliti diterima dengan baik dan lebih leluasa dalam memperoleh data yang diharapkan. Kemudian peneliti melakukan pengamatan lebih mendalam, wawancara dan mengumpulkan data-data dari dokumentasi.

3. Tahap Analisis Data, Pada tahapan ini peneliti menyusun semua data yang telah terkumpul secara sistematis dan terinci sehingga data tersebut mudah dipahami dan temuannya dapat diinformasikan kepada orang lain secara jelas. Setelah peneliti mendapatkan data yang cukup dari lapangan, peneliti melakukan analisis terhadap data, kemudian menelaahnya, membagi dan menemukan makna dari apa yang telah diteliti.

4. Tahap Pelaporan, pada tahap ini merupakan tahap terakhir dari tahapan penelitian yang peneliti lakukan. Tahap ini dilakukan dengan membuat laporan tertulis dari hasil penelitian yang telah dilaksanakan. 
HASIL

Hasil temuan dan pembahasan mengenai efektivitas kepemimpinan kepala sekolah dalam kemampuan guru dalam menyusun RPP bahwa ada beberapa hal yang dilakukan kepala sekolah guna meningkatkan kemampuan guru, diantaranya:

a. Kepemimpinan Manajerial

Kepala sekolah berperan penting dalam meningkatkan kinerja guru, hal ini tidak terlepas dari tanggung jawab kepala sekolah sebagai seorang pimpinan lembaga pendidikan. Keberhasilan sekolah merupakan keberhasilan kepala sekolah. Kunci utama kepala sekolah sebagai pemimpin yang efektif adalah dapat mempengaruhi dan menggerakan guru untuk ikut berpartisipasi dalam setiap kegiatan sekolah guna mewujudkan visi dan misi sekolah. Adapun kemampuan manajerial kepala Sekolah MAS Al Ikhwan Serapuh dalam meningkatkan penyusunan RPP bagi guru, diantarnya:

1. Mengarahkan guru dalam merumuskan tujuan pembelaran yaitu merumuskan tujuan pembelajaran dapat dijadikan acuan bagi guru dalam mengantarkan siswa belajar, sebagai panduan dalam memilih materi pelajaran, menentukan strategi pembelajaran dan memilih alatalat pembelajaran yang akan digunakan, sekaligus sebagai dasar menyusun alat penilaian hasil belajar.

2. Mengarahkan pelaksanaan kegiatan pembelajaran bagi guru yaitu kepala sekolah bertugas mengarahkan dalam pengelolaan pembelajaran, sehingga pengelolaan yang dilakukan guru sejalan dengan visi, misi dan tujuan pendidikan disekolah. Kepala sekolah dengan pengalamannya dibidang pendidikan dapat membantu guru mengatasi berbagai problematika pengelolaan pembelajaran yang dihadapi. Berkaitan dengan peran kepala sekolah dalam mengarahkan guru mengelola pembelajaran.

3. Mengawasi (supervisi) Kelancaran Kegiatan Pembelajaran bagi Guru. Adapun berkaitan dengan peranan kepemimpinan kepala sekolah 
melakukan pengawasan atau supervisi pendidikan dalam meningkatkan kinerja guru dalam penyusunan RPP.

4. Evaluasi Pelaksanaan Kegiatan pembelajaran bagi Guru. Penilaian hasil kegiatan pembelajaran merupakan proses pengumpulan informasi dan data tentang pencapaian pembelajaran siswa dalam aspek sikap, pengetahuan dan keterampilan yang dilakukan secara terencana dan sistematis yang dilakukan untuk memantau proses, kemajuan belajar dan perbaikan hasil belajar. Berkaitan dengan peranan kepala sekolah dalam mengarahkan dan membantu guru dalam hal penilaian hasil belajar. Peranan kepala sekolah dalam mengarahkan guru melakukan penilaian hasil belajar yang dilakukan melalui koordinasi terkait kebijakan pelaksanaan ujian tengah semester, pembagian raport dan rapat evaluasi akhir semester. Kepala sekolah juga membentuk panitia ujian yang bertanggung jawab terhadap pelaksanaan ujian sekolah.

b. Sosialiseme Kepala Sekolah

Upaya kepala sekolah sebagai dampak positif di Madrasah Aliyah Swasta Al Ikhwan Serapuh dengan mewujudkan melalui partisipasi sekolah kedalam berbagai macam kegiatan dalam hubungan yang baik secara pihak internal maupu ekstranal, sehingga kemampuan kepala sekolah dalam kinerja guru untuk meningkatkan penyusunan RPP meliputi:

1. Hubungan kepala sekolah dengan pihak internal sekolah Menjalin hubungan yang baik dengan para masyarakat di dalam sekolah merupakan kemampuan kepala sekolah dalam berkomunikasi dan memberikan apa yang dibutuhkan kepada masyarakat yang ada di sekolah. berkomunikasi untuk menjalin hubungan yang baik juga kepala sekolah mengadakan kegiatan-kegiatan untuk guru dan staff, seperti kegaitan rapat yaitu dengan bersama-sama menyusun program sekolah baik untuk guru maupun siswa. Kepala sekolah memiliki salah satu fungsi yaitu sebagai administrator, kepala sekolah sebagai administrator harus memiliki kemampuan dalam megelolah segala sumber daya yang ada di sekolah, baik dari sumber daya manusia yaitu 
guru, para staf, dan siswa, serta berbagai fasilitas yang ada di sekolah. Terkusus dalam meningkatkan penyusunan RPP bagi guru, kepala sekolah memberikan arahan dan bimbingan dan arahan agar sekiranya guru telah memiliki RPP dalam pelaksanaan proses mengajar di Madrasah Aliyah Swasta Al Ikhwan Serapuh.

2. Hubungan kepala sekolah dengan pihak eksternal sekolah

Kepala sekolah selalu menjaga hubungan baik dengan para orang tua dan masyarakat lingkungan sekolah. Kepala sekolah selalu memberikan informasi terkait sekolah kepada masyarakat terutama orang tua wali murid. Menjalin hubungan yang baik dengan masyarakat luar sekolah merupakan tugas dari kepala sekolah dalam mengkomunikasikan informasi terkait dengan sekolah. Informasi yang diberikan dapat berupa surat ederan maupun tatap muka langsung dengan mengadakan pertemuan dengan wali murid. Dalam menjalin hubungan dengan pihak eksternal sekolah, kepala sekolah mengadakan kegiatan-kegiatan yang melibatkan masyarakat seperti Rapat orang tua wali murid, acara PHBI (acara memperingati Maulid Nabi Muhammad SAW, acara Isra Miraj, acara tahun 10 Muharram, perlombaan 17 Agustus, acara perpisahaan atau wisuda santri), kegaitan hari raya Qurban, perlombaan pensi (pentas seni Islam) dan lainnya.

\section{c. Profesionaliseme Kepala Sekolah}

Segi profesionalisme sebagai bagian dari kepemimpinan kepala sekolah, berbagai upaya telah dilakukan seperti memajukan sekolah dengan mengadakan program-program unggulan sebagaimana ungkapan kepala sekolah bahwa pertama dilakukan yakni meningkatkan kompetensi guru untuk meningkatkan kualitas belajar, dilanjutkan dengan membuat program unggulan, kemudian civitas sekolah melengkapi segala administrasi sekolah, selanjutnya dibentuk ekskul yang sesuai dengan minat dan bakat siswa, serta tak lupa menjalin hubungan baik dengan guru, siswa dan masyarakat. Beberapa program unggulan saat ini yang sudah diterapkan berupa tahfidz qur'an, praktek ibadah, muhadastah 
(percakapan bahasa arab), perencanaan penerapan conversation class (percakapan bahasa inggris) dalam waktu dekat.

Meningkatkan mutu pendidikan di sekolah, implementasinya melibatkan seluruh elemen, seperti: kepala sekolah, wakepsek, dewan guru, tata usaha, komite sekolah. Jadi semuanya bekerja sama hingga tujuan sekolah dapat dicapai secara maksimal. Sebab, keseluruhan akan berjalan sebagaimana harapan apabila semuanya saling bahu-membahu.

d. Keefektifan kepemimpinan kepala sekolah dalam meningkatkan kompetensi guru menyusun RPP.

Guru diwajibkan untuk melengkapi tugas yang sudah menjadi tanggung jawabnya sebagai seorang pendidik, yaitu memiliki rancangan pembelajaran, sebagaimana diketahui bahwa Sebelum pembelajaran dimulai, seluruh dewan guru harus membuat dan mengumpulkan RPP sesuai dengan mata pelajaran yang diampunya. Selaku guru, sudah selayaknya memahami mengenai KD, KI, Materi dan Tujuan RPP yang telah dibuat.

Secara teknis untuk KI dan KD memang sudah mengikuti acuan dari Permendikbud No.37 Tahun 2018. Hanya saja dalam pemahaman dan kesesuaian di RPP terkadang hanya berupa kelengkapan administrasi semata. Hendaknya perlu sedikit pembekalan hingga mereka mengerti dan memahami komponen yang terkandung dalam RPP. Beberapa keinginan yang diharapkan dari kepsek sebagai pemimpin disini guna meningkatkan kinerja guru ialah menjadi motivator untuk para guru. Sebab, dukungan/motivasi yang diberikan oleh atasan memiliki magnet tersendiri yang membuat guru untuk menjadi lebih baik lagi. Hal tersebut dapat dibuktikan dengan terwujudnya kepemimpinan kepsek yang acapkali memberikan dorongan dan motivasi kepada guru bagi secara langsung maupun tidak langsung sebagaimana semboyan Ki Hajar Dewantara : ing ngarsa sung tuladha, ing madya mangun karsa tut wuri handayani (di depan memberi contoh, di tengah bekerjasam, dibelakang mendorong/memotivasi). 


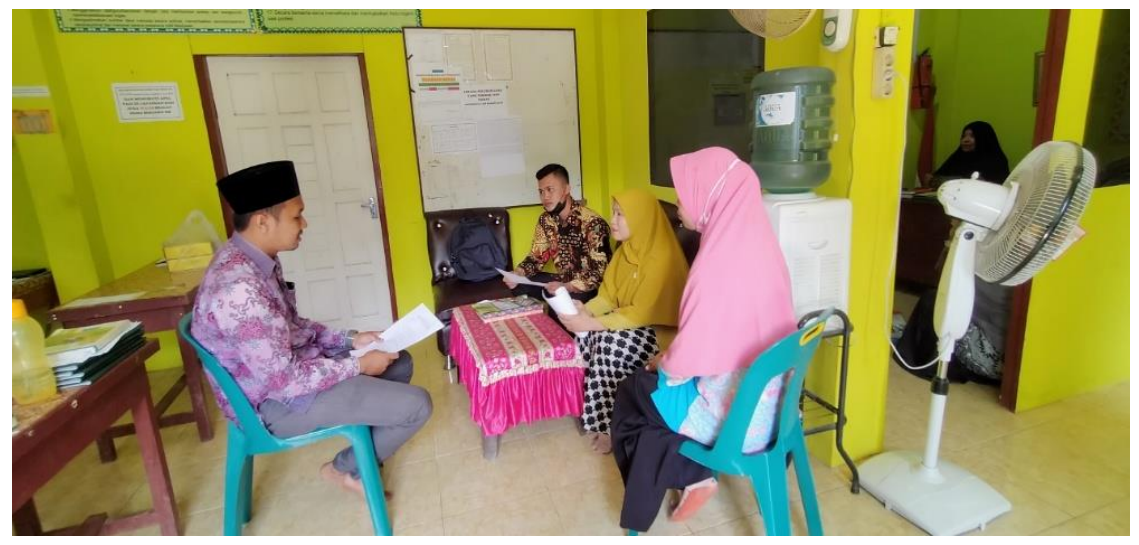

Gambar 1. Dokumentasi Wawancara Peneliti dengan Kepala Sekolah Madrasah Aliyah Swasta Assalam Serapuh

Kesimpulan bahwa dampak positif dan negatif selalu beriringan. Artinya, tidak semua mampu menjangkau seca keseluruhan hingga sesuai keinginan. Ada beberapa diantaranya yang kurang dari kata maksimal. Oleh sebab itu, setiap apa yang dilakukan menanggung dua dampak yang dapat dilihat dari besar arah kecenderungannya pada hal yang mana. Dalam hal ini ditunjukkan ke arah yang baik tentunya.

\section{PEMBAHASAN}

Menurut Permendiknas Nomor 41 Tahun 2007, Rencana Pelaksanaan Pembelajaran (RPP) adalah rencana yang menggambarkan prosedur dan pengorganisasian pembelajaran untuk mencapai satu kompetensi dasar yang ditetapkan dalam standar isi dan telah dijabarkan dalam silabus. Sedangkan menurut Kemendikbud Nomor 22 tahun 2016, RPP merupakan rencana kegiatan pembelajaran untuk dilaksanakan pada satu hari atau lebih yang dikembangkan dari silabus menjadi salah satu perangkat pembelajaran yang harus dibuat oleh pendidik/guru.

RPP bertujuan menciptakan pembelajaran yang interaktif, terarah, efektif, efisien, menarik, menyenangkan, menantang dan mampu memberikan motivasi terhadap peserta didik dalam upaya pencapaian KD. Prinsip dari pengembangan RPP dalam Permendikbud Nomor 22 tahun 2016 (Rahayu dan Septian 2020), yakni:

a) Perbedaan indivisual peserta didik; 
b) Partisipasi aktif peserta didik

c) Berpusat pada peserta didik

d) Pemgembangan budaya membaca dan menulis

e) Pemberian umpan balik

f) Penekatan pada keterkaitan KD, materi, IPK, Penilaian dan sumber belajar

g) Akomodasi pembelajaran tematik-terpadu

h) Penerapan TIK

Agar guru memiliki kompetensi yang baik dalam menyusun RPP, maka guru perlu dilatih agar dapat menyusun RPP dengan baik dan benar. Melalui pelatihan permasalahan mengenai kesenjangan kemampuan guru dalam menyusun RPP akan dapat dipecahkan, sehingga guru tidak mengalami kesulitan lagi dalam membuat RPP. Perencanaan dan pelaksanaan pelatihan yang matang berkaitan juga dengan tugas dan fungsi kepala sekolah, sehingga dapat dipadukan dengan kegiatan supervisi melalui adanya pelatihan untuk meningkatkan kualitas RPP di suatu lembaga sekolah.

Berdasarkan hasil penelitian, Kontradikai antara konsep di atas dengan hasil yang didapatkan yakni kurangnya patrsipasi aktif dan rasa menyenangkan dalam pembelajaran. Sebabm RPP yang ada pada dasarnya hanya untuk pemenuhan tanggung jawab guru kepada sekolah, bukan sebagai panduan guru dalam mengajar di kelas. Implikasinya, kesesuaian harapan tidak relevan. Dengan begitu diharapkan agar terus memperbaiki kompetensi/kemampuannya dalam menyusun RPP sehingga peningkatan dalam proses pembelajaran terus mengalami perubahan sebab sudah memalui perencanaan yang matang.

\section{KESIMPULAN}

Berdasarkan hasil analisis dan pembahasan dapat ditarik kesimpulan sebagaimana berikut:

a. Dari sisi Kepemimpinan Manajerial yang menunjukkan hasil bahwa peran kepala sekolah dalam meningkatan penyususnan RPP bagi guru Madrasah Aliyah Swasta Al Ikhwan Serapuh diantaranya :

1. Mengarahkan guru merumuskan tujuan pembelajaran, dilakukan dengan meningkatkan pengetahuan guru dengan mengirim guru ke 
forum KKG, penataran, atau diklat yang diadakan pemerintah dalam pelatihan peningkatan kompetensi guru dalam menyusun RPP di bidang studinya masing-masing

2. Mengarahkan pelaksanaan kegiatan pembelajaran, dengan memberikan pengarahan, memberikan motivasi kepada guru dalam penyusunan RPP.

3. Mengawasi kelancaran kegiatan, melakukan pengawasan atau supervisi langsung dengan cara berkunjung ke setiap kelas untuk melihat guru dalam proses pembelajaran.

4. Menilai pelaksanaan kegiatan, dalam hal penilaian belajar kepala sekolah membentuk panitia evaluasi hasil belajar yang terdiri dari guru dan staf sekolah.

b. Dari sisi sosialisme kepala sekolah diketahui bahwa kompetensi sosial kepala sekolah dalam Menjalin hubungan yang baik dengan pihak internal dan eksternal sekolah yaitu dengan pelaksanaan kegiatan-kegiatan. Adapun kegaitan-kegaitan yaitu rapat rutin dengan kepala sekolah dengan dewan guru, rapat dengan orang tua wali murid, mengadakan PHBI (acara maulid, acara isra miraj, acara perpisahan atau wisuda santri), perlombaan pentas seni, dan menjelain hubungan dengan pemerintah daerah dan dinas pendidikan.

c. Dari sisi Profesionalisme kepala sekolah didapati bahwa secara keseluruhan kepala sekolah mampu menjadi acuan bagi para dewan guru untuk dapat dicontoh. Hal tersebut ditunjukkan dari kemampuannya dalam mengayomi, memberi contoh dan menyelesaikan persoalan serta berdedikasi pada lembaganya.

d. Keefektifan Kepemimpinan Kepala Sekolah dalam Meningkatkan Kompetensi Guru Menyusun RPP, diperoleh hasil bahwa sebagian besar guru sudah bisa untuk mandiri dalam membuat-menyusun RPP. Tetapi ditemukan beberapa diantaranya hanya sekadar memenuhi administrasi, hal ini disebabkan karena menyalin ulang tanpa mengerti-memahami keseluruhan isinya. 


\section{DAFTAR PUSTAKA}

Badeni. 2013. Kepemimpinan Dan Prilaku Organisasi. Bandung: Alfabeta.

Danim, Sudarwan. 2004. Motivasi Kepemimpinan \& Efektivitas Kelompok. Jakarta: Rineka Cipta.

Fuadi, Ahmad dan Arafah, Novira dan Zahra, Fatimah, Azmi, Maulida. 2020. Administrasi Pendidikan. Jakarta.

Kamiludin. 2021. "Jajang, Pelaksanaan In House Traaining (IHT) Untuk Meningkatkan Kemampuan Guru Dalam Menyusun RPP.” Jurnal Pedagogiana: Journal of Basic Education, No. 498.

Marpaung, Marudut. 2014. "Pengaruh Kepemimpinan Dan Team Work Kemdikbud, Terhadap Kinerja Karyawan Di Koperasi Sekjen Jakarta, Senayan.” Jurnal Ilmiah Widya No.1. Hal: 35- Jakarta., 36.Jakarta: STIE Dharma Bumiputra 2: 35.

Mesiono. 2012. Manajemen dan Organisasi, Bandung: Citapustaka Media Perintis

Novira Arafah dan Nurika Khalila Daulay.2017. "Pengaruh Kepemimpinan Kepala Madrasah terhadap Profesionalisme Guru di MAN 1 Tanjung Pura." Jurnal TADBIR UINSU Hal: 191-198

Rahayu dan Septian, Galih Dani. 2020. Mudah Menyusu Perangkat Pembelajaran. Purwakarta: Tre Alea Jacta Pedagogie.

Sangad. 2016. "Meningkatkan Kemampuan Guru Dalan Penyusunan RPP Yang Berkarakter Melalui Supervisi Akademik.” Jurnal Edukasi, Universitas Galuh.

Sugiyono. 2010. Metode Penelitian Pendekatan Kuatitatif, Kualitatif Dan R Dan D. Bandung: Alfabeta.

Syafaruddin dan Asrul, (2013), Kepemimpinan Pendidikan Kontemporer, Bandung: Citapustaka Media. 